Article

\title{
The Deterioration of Morocco's Vegetable Crop Genetic Diversity: An Analysis of the Souss-Massa Region
}

\author{
Stuart Alan Walters ${ }^{1, *}$, Rachid Bouharroud ${ }^{2}$, Abdelaziz Mimouni ${ }^{2}$ and Ahmed Wifaya ${ }^{2}$ (1) \\ 1 Department Plant, Soil, and Agricultural Systems, Southern Illinois University, Carbondale, IL 62901 USA \\ 2 Integrated Crop Production Unit, National Institute of Agronomic Research, Regional Center of Agadir, \\ Agadir 80350, Morocco; bouharroud@yahoo.fr (R.B.); mimouniabdelaziz@yahoo.fr (A.M.); \\ wifaya_ahmed@yahoo.fr (A.W.) \\ * Correspondence: awalters@siu.edu; Tel.: +1-618-4532496
}

Received: 7 March 2018; Accepted: 28 March 2018; Published: 30 March 2018

\begin{abstract}
Crop domestication and breeding efforts during the last half-century in developed countries has significantly reduced the genetic diversity in all major vegetable crops grown throughout the world. This includes developing countries such as Morocco, in which more than $90 \%$ of all farms are less than 10 ha in size, which are generally maintained by subsistence farmers who try to maximize crop and animal productivity on a limited land area. Near Agadir, in the remote Anti-Atlas mountain areas of the Souss-Massa region, many small landowner vegetable growers are known to still utilize crop populations (landraces). Thus, an assessment of the current status of vegetable landraces was made in this mountainous region of Southwestern Morocco during 2014. This assessment indicated that a significant loss of vegetable crop landraces has occurred in the last 30 years in this region of Morocco. Although many vegetable crops are still maintained as landrace populations by small subsistence farmers in remote areas in the Souss-Massa region, only $31 \%$ of these farmers cultivated landraces and saved seed in the villages assessed, with the average farmer age cultivating landraces being 52 years old. Moreover, the approximated loss of vegetable crop landraces over the last 30 years was an astounding 80 to $90 \%$. Vegetable crops notably lost during this time period included carrot (Daucus carota), fava beans (Vicia faba), melon (Cucumis melo), pea (Pisum sativum), watermelon (Citrullus lanatus), and tomato (Solanum lycopersicon). The most significant loss was tomato as no landraces of this crop were found in this region. The vegetable crop landraces that are still widely grown included carrot, melon, onion (Allium cepa), turnip (Brassica rapa var. rapa), and watermelon, while limited amounts of eggplant (Solanum melongea), fava bean, pea, pepper (Capsicum annuиm), and pumpkin (Cucurbita moshata and C. maxima) were found. This recent genetic deterioration will have a profound influence on future Moroccan agricultural productivity, as the genetic diversity within these landraces may be the only resource available to allow these smaller subsistence farmers to cope with changing environmental conditions for the optimization of crop production in their harsh climate.
\end{abstract}

Keywords: crop population; genetic resources; genetic variability; germplasm; landrace

\section{Introduction}

The domestication of improved vegetable genotypes through breeding efforts during the last half-century has significantly reduced the genetic diversity in all major vegetable crops grown throughout the world. Growers and consumers alike have become accustomed to the high quality and yields of hybrid vegetable cultivars, which has definitely resulted in a significant reduction in 
cultivation of landraces (or local varieties). Landraces are dynamic populations of a genetically-diverse, locally-adapted cultivated plant species that have historical origins, distinct identity, no formal crop improvement, and are oftentimes associated with traditional farming systems [1]. Although landraces generally have high genetic diversity and heterogeneity, they oftentimes will provide inconsistent phenotypes with overall lower quality and yields compared to newer hybrids or pure-line inbreds.

Vegetable crops grown in sustainable, low-input, traditional farming systems have traditionally been landraces. However, the cultivation of vegetable landraces has decreased since the widespread use of improved hybrid cultivars [2]. Since the first modern hybrid varieties were released more than 50 years ago, the areas planted to these improved varieties continue to expand [3]. Vegetable crop landrace cultivation has also diminished even in remote areas in developing countries, especially within the last few decades [4]. Landraces throughout the world are rapidly being lost, due to increasingly more limited use by growers in many areas of the world [2,3]; and, lower amounts of field cultivation, multiplication, and conservation by growers directly relates to the loss of this valuable genetic resource over time. Fewer and fewer subsistence farmers are cultivating landraces and maintaining seed stock from year to year. The loss of landrace populations is devastating to the vegetable crop species gene pool, as genes that have evolved over millennia are being lost. The main contributions of landraces to the development of new crop varieties have been traits for more efficient nutrient uptake and utilization, as well as genes for adaptation to stressful environments, such as water stress, salinity, and high temperatures [5]. Thus, landraces are an important diverse genetic resource that allows crop species to adapt to local effects of climate and pests, and to eventually produce improved yields unique to a specific environment, especially those that impose some type of stressful conditions on the growing crops. Crop genetic resources are crucial for the future survival of humanity, and future food security depends upon their conservation $[6,7]$.

Morocco is a rapidly developing country and has great agricultural export markets in place due to its proximity to Europe. However, more than $90 \%$ of all farms are less than 10 ha, and these farms produce most of the vegetable crops that feed the populace [4]. There are some larger-sized farms that produce vegetables, but these tend to be financed from developed countries in Europe, especially France and Spain. Similar to other developing countries, income is very limited in Morocco (especially in rural areas) and most farmers must try to maximize productivity on a limited amount of land while trying to use minimal inputs. The Souss-Massa region of Morocco is an important agricultural area within this country, as it produces significant amounts of vegetables for both domestic and export sales. Agadir is the capital of this region, which is located in the southwestern portion of the country along the Atlantic coast. The villages immediately surrounding the city to the south are well known for their large-scale vegetable production operations, with products (especially greenhouse tomatoes) extensively grown for export to European markets. However, in remote areas of the Souss-Massa (especially in mountainous areas), most vegetable growers are subsistence farmers who minimize inputs to grow vegetable crops and typically sell their produce at local weekly markets (or souks). In past years, these small subsistence growers in rural areas of the Souss-Massa primarily relied upon seed from vegetable landraces for their crop production needs. The use of vegetable landraces resulted primarily due to the remoteness of these farmers, as well as the lack of contact to the outside world, which prevented access to other seed sources. However, the world has drastically changed in the last few decades and, today, there is readily available access to anything that anyone with money would desire even in remote areas of the world. Thus, the relatively small returns that landraces provide compared to the apparently overwhelming advantages that modern varieties seem to offer farmers are oftentimes not enough to maintain their utilization in a particular farming system [8]. Therefore, the objective of this study was to conduct an assessment of vegetable landraces in mostly remote areas within the Souss-Massa region of Morocco. 


\section{Materials and Methods}

\subsection{Study Area}

This landrace assessment was conducted in the Souss-Massa region of Morocco. This area includes Agadir, a city of approximately 750,000 people, which has significant Berber influence, with an arid to semi-arid climate. Temperatures range from highs of $\sim 40$ to $45^{\circ} \mathrm{C}$ in July and August to lows of $\sim 2$ to $4{ }^{\circ} \mathrm{C}$ in January. There is minimal rainfall with only 150 to $250 \mathrm{~mm}$ received annually, with little occurring from May to September, which is typically a very dry time of the year. More than $90 \%$ of the farmers in this region are small landholders, especially those in remote areas of the Anti-Atlas Mountains, and generally have only between 5 and 10 ha. This environment is oftentimes dry and hot which provides significant stress for plant growth and survival. The landscape of a typical, small subsistence farm in the Anti-Atlas mountains of Southwestern Morocco (near the village of Tizi N' Test) is provided in Figure 1.

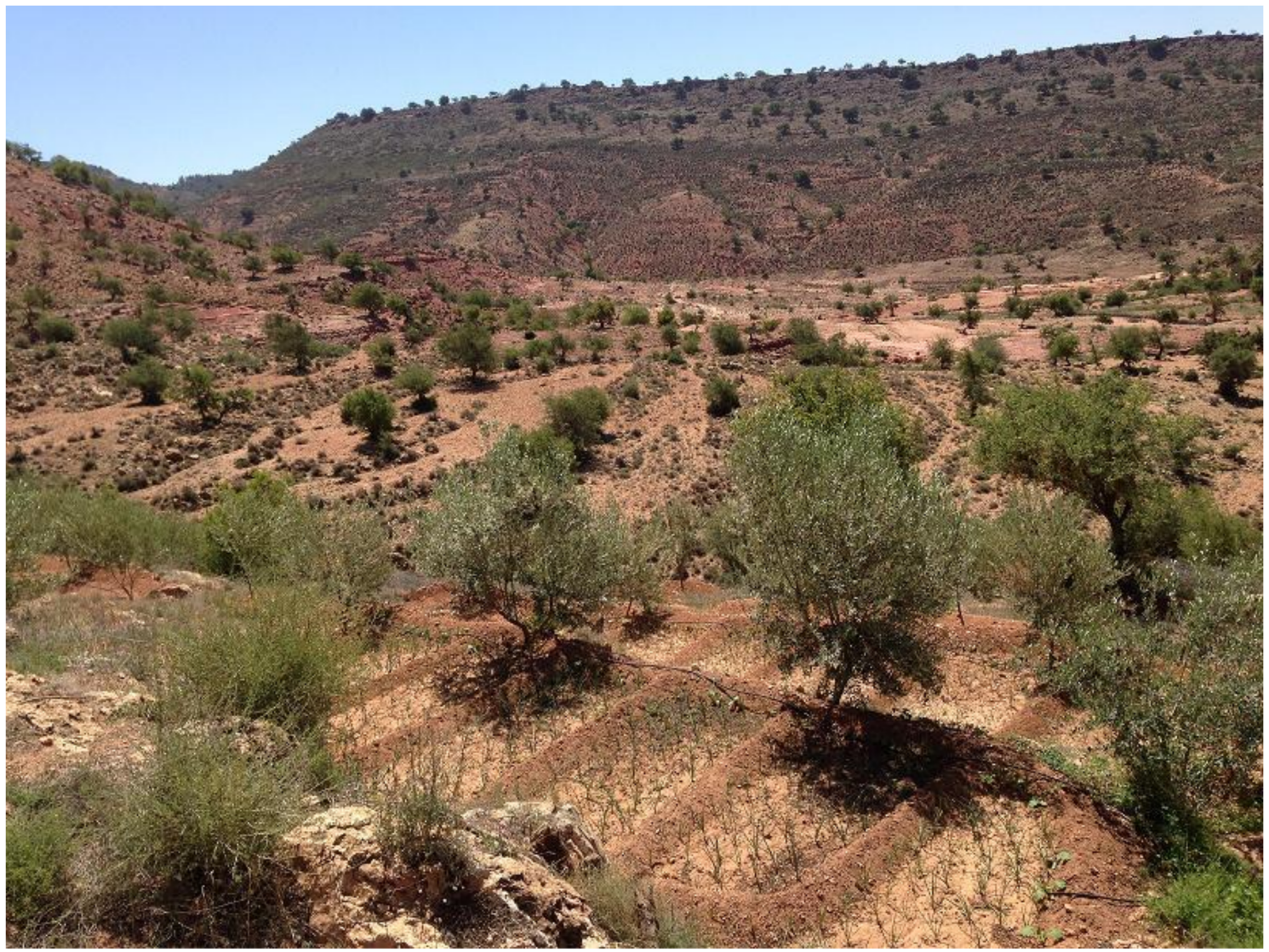

Figure 1. Landscape of a typical, small subsistence farm in Anti-Atlas mountain region of Southwestern Morocco. Notice the onions growing in the basin irrigation beds underneath the olive trees.

\subsection{Vegetable Landrace Assessment and Data Collection}

During April 2014 a vegetable landrace assessment was conducted in the Souss-Massa region of Morocco. Six localities were visited to assess landraces in this region, and all were between latitudes $29.1620145^{\circ}$ and $30.531266^{\circ} \mathrm{N}$, and longitudes $-9.636919^{\circ}$ and $-7.923879^{\circ} \mathrm{W}$. The villages visited during the assessment were: Anou eljdid (30.162045, -9.252229); Biougra (30.220658, -9.372859); Massa (30.004087, -9.636919); Targa N' Touchka (29.885070, -9.199597); Taliouine (30.531266, -7.923879); and, Tizi N' Test (30.868223, -8.379130). The approximate location of each village in Southwestern Morocco is provided in Figure 2. Farmers were identified in each village and asked specific questions regarding landrace cultivation (Table 1). They provided answers to: total number 
of vegetable growers in each village, percentage of growers cultivating vegetable landraces and saving seed each year, average age of famers cultivating landraces, estimated percentage of vegetable crop landraces lost during the last 30 years, current vegetable landraces cultivated, and vegetable crop species landraces lost during the last 30 years. Seed were collected from the landraces that the farmers would provide to us and placed at the National Institute for Agronomic Research (INRA) in Settat, Morocco.

\subsection{Data Analysis/Presentation}

The data collected for the vegetable landrace assessment conducted in the Souss-Massa region of Morocco were compiled and placed into tabular form. The specific questions asked of famers in each village related to vegetable crop landraces were collated with overall means also determined for this data. Additional information collected regarding the vegetable crop landraces currently grown, as well as those lost over the last 30 years is also presented.

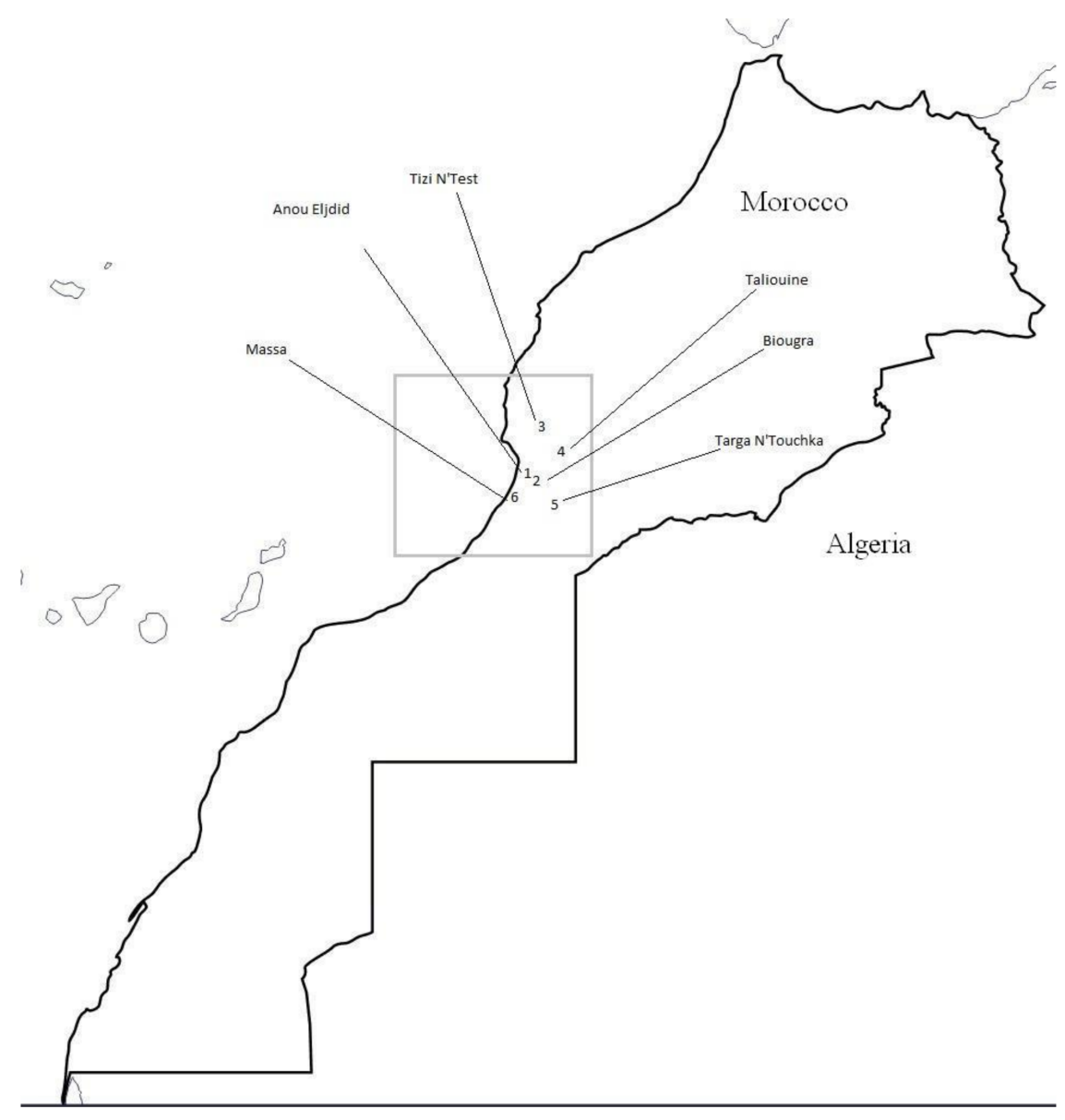

Figure 2. Approximate locations of the six villages in the Souss-Massa region of Morocco that were assessed for vegetable landrace use. The latitude $\left({ }^{\circ} \mathrm{N}\right)$ and longitude $\left({ }^{\circ} \mathrm{W}\right)$ of each village: Anou eljdid (30.162045, -9.252229); Biougra (30.220658, -9.372859); Massa (30.004087, -9.636919); Taliouine (30.531266, -7.923879); Targa N' Touchka (29.885070, -9.199597); and Tizi N'Test (30.868223, -8.379130). 
Table 1. Questions provided to small subsistence farmers cultivating vegetable crop landraces in six villages within the Souss-Massa region of Morocco in 2014.

\begin{tabular}{l}
\hline Questions: \\
\hline What are the total number of vegetable growers in your village? \\
What is the percentage of growers cultivating vegetable landraces and saving seed each year in your village? \\
What is the average age of famers cultivating vegetable landraces in your village? \\
What is the estimated percentage of vegetable crop landraces that you think has been lost during the last 30 years? \\
What are the vegetable landraces currently cultivated in your village? \\
Which vegetable crop species landraces have been lost during the last 30 years? \\
\hline The latitude $\left({ }^{\circ} \mathrm{N}\right)$ and longitude $\left({ }^{\circ} \mathrm{W}\right)$ of each village assessed: Anou eljdid $(30.162045,-9.252229) ;$ Biougra \\
$(30.220658,-9.372859) ;$ Massa $(30.004087,-9.636919) ;$ Taliouine $(30.531266,-7.923879) ;$ Targa $\mathrm{N}^{\prime}$ Touchka (29.885070, \\
$-9.199597) ;$ and Tizi $\mathrm{N}^{\prime}$ Test $(30.868223,-8.379130)$. Estimates for data presented in table based on conversations \\
with small vegetable growers in each village.
\end{tabular}

\section{Results}

\subsection{Farmer Demographics Related to Vegetable Landraces}

The assessment indicated that there are relatively few small, subsistence farmers in the Souss-Massa region of Morocco that maintain vegetable landrace populations (Table 2). In the villages assessed, only about $31 \%$ of the small growers cultivated landraces and saved seed, although the range was from a low of $20 \%$ in Tizi $\mathrm{N}^{\prime}$ Test to a high of $45 \%$ in Targa $\mathrm{N}^{\prime}$ Touchka. This trend is disturbing, as growers are placing more reliance on other types of seed compared to landraces, which can have disastrous results for future vegetable crop production due to the increased lack of diversity that is being perpetuated in these production systems.

Table 2. Assessment of small, subsistence farmers cultivating vegetable crop landraces in six villages within the Souss-Massa region of Morocco in 2014, and estimated percentage of landraces lost in those villages over the last 30 years.

\begin{tabular}{|c|c|c|c|c|}
\hline $\begin{array}{c}\text { Moroccan } \\
\text { Souss-Massa } \\
\text { Region Village }\end{array}$ & $\begin{array}{l}\text { Total No. of } \\
\text { Growers in } \\
\text { Village }\end{array}$ & $\begin{array}{l}\text { Percent of Growers } \\
\text { Cultivating Landraces } \\
\text { and Saving Seed }\end{array}$ & $\begin{array}{l}\text { Farmer Age } \\
\text { Cultivating } \\
\text { Landraces }\end{array}$ & $\begin{array}{c}\text { Percent Landraces } \\
\text { Lost in Last } \\
30 \text { Years }\end{array}$ \\
\hline Anou eljdid & 8 & 37 & 50 & 80 \\
\hline Biougra & 8 & 25 & 52 & 90 \\
\hline Massa & 15 & 33 & 55 & 90 \\
\hline Taliouine & 13 & 23 & 45 & 80 \\
\hline Targa N' Touchka & 20 & 45 & 55 & 80 \\
\hline Tizi N' Test & 10 & 20 & 55 & 90 \\
\hline
\end{tabular}

The average age of farmers cultivating landraces was 52 years old, and ranged between 45 in Taliouine, 50 in Anou eljdid, 52 in Biougra, and 55 in Massa, Targa N' Touchka, and Tizi N' Test (Table 2). The small number of growers cultivating vegetable landraces along with aging farmer populations have most likely directly resulted in the loss of landraces over time. This assessment indicated that there are few young farmers involved in the vegetable cultivation and the seed-saving process in the Souss-Massa region of Morocco, which is similar to many other areas of the world in which the younger generation has little to no interest in farming as a profession.

The estimated loss of vegetable crop landraces over the last 30 years by farmers in the villages assessed was an astounding $85 \%$ (Table 2). Three villages, Biougra, Massa, and Tizi $\mathrm{N}^{\prime}$ Test, had experienced the loss of $90 \%$ of vegetable landraces over the last 30 years, while the other villages assessed was estimated at $80 \%$. This estimated loss of vegetable crop diversity in this region of Morocco is much more than expected, and this trend is expected to continue in the near future. 


\subsection{Vegetable Crops as Landraces}

Numerous vegetable crop landraces have been lost during the last 30 years in the Souss-Massa region of Morocco (Table 3). The complete loss of tomato landraces during the last 30 years was entirely unexpected, as five of the six villages assessed (or $83 \%$ ) had recently grown landraces of tomato that are now totally lost. Other significant vegetable crop landrace losses in Souss-Massa villages during this time period were melon $(67 \%)$, watermelon and fava bean $(50 \%)$, and carrot and pea $(17 \%)$. The significant losses of vegetable crop landraces in these villages during the last 30 years were expected, but not at the high levels that were determined from this assessment.

Although many vegetable crop landraces have declined over the last 30 years, many are still widely grown in this region, including carrot, melon, onion, pumpkin, turnip, and watermelon (Table 3). There were limited amounts of other vegetable landraces cultivated in this region, and included eggplant, fava bean, pea, and pepper; these were all found in Tizi $\mathrm{N}^{\prime}$ Test, as none of the other locations evaluated grew landraces of these crops. Melon and onion landraces were the most prevalent throughout this region of Morocco, with $67 \%$ of the villages assessed currently growing landraces of these crops. Other important vegetable crop landraces grown were pumpkin, turnip, and watermelon, which were found in $33 \%, 50 \%$, and $33 \%$ of villages assessed, respectively. The cultivation of yellow carrot landraces in half the villages was also unexpected. It appears that yellow carrots are a regional specialty and are often used as a substitute for the more traditional orange carrots that are oftentimes used in couscous. Interestingly, no tomato landraces were identified in any village assessed (Table 3).

Table 3. Vegetable crop landraces currently grown, and those lost over the last 30 years based on an assessment of small, subsistence farmers in six villages in the Souss-Massa region of Morocco in 2014.

\begin{tabular}{|c|c|c|}
\hline $\begin{array}{l}\text { Moroccan Souss-Massa } \\
\text { Region Village }\end{array}$ & $\begin{array}{c}\text { Current Cultivated Vegetable } \\
\text { Crop Landraces }\end{array}$ & $\begin{array}{c}\text { Vegetable Crop Landraces Lost } \\
\text { within Last } 30 \text { Years }\end{array}$ \\
\hline Anou eljdid & carrot (yellow), melon, turnip & $\begin{array}{l}\text { carrot, fava bean, melon, pumpkin, } \\
\text { watermelon, tomato }\end{array}$ \\
\hline Biougra & melon, onion, watermelon & melon, tomato \\
\hline Massa & melon, onion, watermelon & tomato \\
\hline Taliouine & carrot (yellow), onion & fava bean, tomato \\
\hline Targa N' Touchka & carrot (yellow), turnip & melon, watermelon \\
\hline
\end{tabular}

\subsection{Vegetable Crop Landraces Still Grown and Maintained}

In addition to providing unique data regarding landraces that are currently cultivated in the Souss-Massa region of Morocco, the number of landraces that are generally maintained by individual farmers was also determined. Some farmers still maintain numerous landraces of several crops, as the farmer visited in Tizi N' Test (Figure 3) maintained a total of 12 vegetable crop landraces, including two each of pumpkin, carrot, and turnip (Table 3). In comparison, farmers in other villages assessed only cultivated and maintained two to three vegetable crop landraces. The utilization of 12 different landraces requires considerable effort for seed-saving activities, such as planning their field location each year to maintain landrace seed purity (especially on a small farm), as well as seed harvesting, cleaning, and storage. This farmer stated that many younger farmers do not use landraces due to all that is required for their maintenance from year to year, and the use of landraces is becoming a lost tradition. 


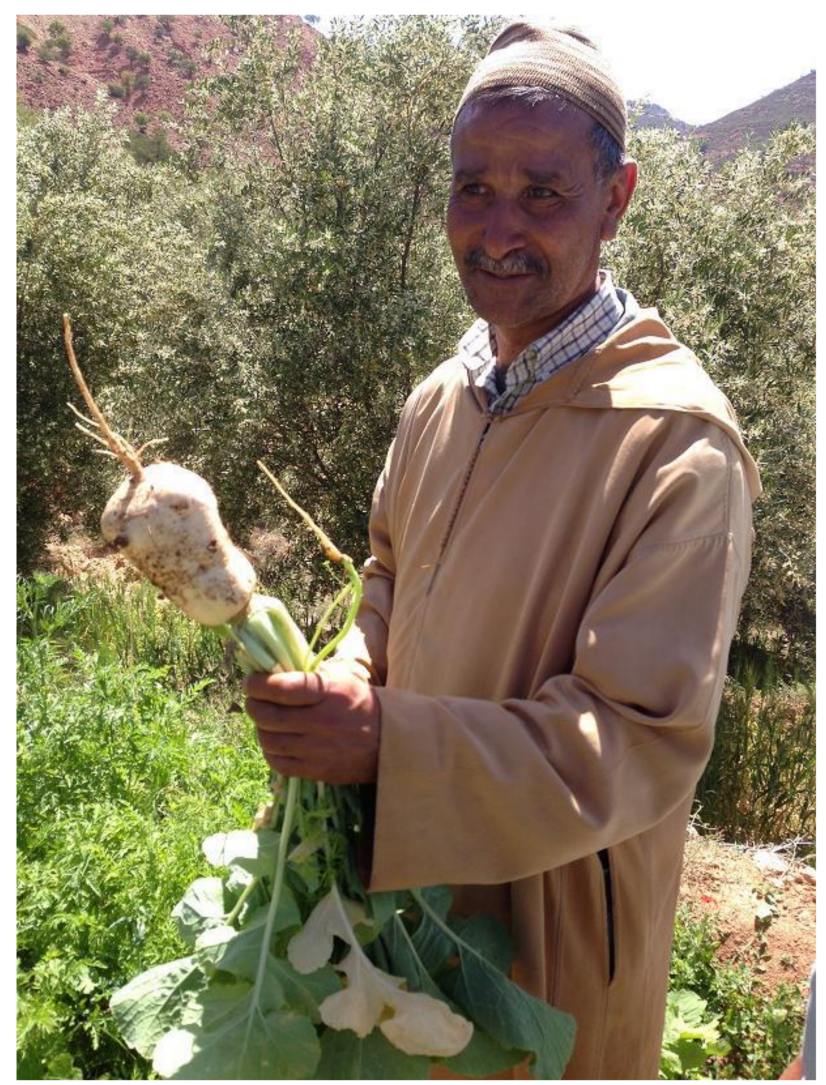

Figure 3. A Moroccan small landholder farmer near the village of Tizi N' Test (in the Anti-Atlas mountain region of southwestern Morocco) showing off his prized turnip. This turnip is a specimen of the landrace that was collected at this location.

\section{Discussion}

\subsection{Vegetable Landrace Overview and Importance}

Landraces of vegetable crops can still be found in many developing countries, but their cultivation is diminishing [4]. The movement toward homogeneity in the world's food supply continues at a rapid rate with no indication of slowing down, and, as a consequence, world food supplies have become more similar in composition, especially important cereal crops [9]. A serious consequence of modern monoculture cropping systems utilizing genetically-uniform hybrids and improved varieties is the significant loss of crop biodiversity through displacement of locally adapted landraces [5]. Plant breeders throughout the world are engaged in developing better and higher yielding varieties of crop plants, with their adoption resulting in at least the partial replacement of the more diverse, genetically-variable, lower yielding, locally-adapted varieties or landraces [10]. Thus, crop genetic uniformity is replacing diversity in many of the world's cropping systems, even with the existing and ongoing genetic diversity management practices of subsistence farmers [11]. Moreover, this crop genetic diversity, which is crucial for most of the world's sustainable agricultural systems that feed most of humanity are being lost at an alarming rate [6]. Genetic diversity is essential to improve crop productivity, to enhance ecosystem functions, and to provide sustainability and adaptability over time [12].

Vegetable crop landraces are often used by small landholders in developing countries and the genetic diversity within these landraces may be the only resource available to allow them to cope with changing environmental conditions to optimize crop production. Landrace populations grown by subsistence farmers may be highly competitive with modern hybrids, especially if they are grown using sustainable minimal-input production practices [13], since landrace populations generally evolved in 
these types of farming systems [14]. Agricultural biodiversity will also be absolutely essential to cope with the predicted impacts of climate change, not simply as a source of genes, but as the base for more resilient farm ecosystems, which is particularly pertinent in areas where diverse production systems still prevail, most notably marginal agricultural areas [12].

\subsection{Significant Genetic Erosion and Loss of Vegetable Landraces}

Our assessment indicated that even in remote areas of the Souss-Massa region of Morocco that were visited, including Taliouine, Targa N' Touchka, and Tizi N' Test, a significant loss of vegetable crop landraces has occurred during the last 30 years with approximately 80 to $90 \%$ of vegetable crop landraces lost during this time (Table 2). This loss has included a diversity of vegetable crops. The most significant loss observed was tomato, as no landraces of this crop species were found in this region, which indicated that tomato landraces that were grown only a few years ago are now completely lost. Much of this deterioration of tomato crop genetic diversity has primarily resulted from activities of large agribusiness farms who export much of their products to Europe. Western nations in Europe demand a high-quality product for their consumers, with hybrid varieties providing the most disease-resistant plants and best quality fruit. Additionally, some of this higher quality fruit is also marketed in Morocco, which drives the domestic market towards the use of hybrids and away from tomato landraces. Furthermore, the Tomato Yellow Leaf Curl Virus (TYLCV), which is transmitted by whiteflies, is a devastating disease of tomato in Morocco, and has also had an influence on perpetuating the use of hybrid tomato varieties. Tomato crops must either have resistance to this disease or be grown in greenhouses with whitefly exclusion screening to prevent this insect from transmitting the pathogen. This situation has directly led to the widespread use of tomato hybrids with TYLCV resistance, since landraces do not have this resistance.

The genetic deterioration of vegetable crop landraces in developing countries, such as Morocco, is disturbing. This should have been expected because they are being quickly replaced in developing countries by newer hybrids, or even older pure-line inbred varieties, which have superior yields and product quality $[4,15]$. Moreover, the recent genetic deterioration of all vegetable crops has directly resulted from consumer demand for superior, high quality vegetable products in the marketplace, even in remote locations of the world [4]. Markets have changed within the last few decades in developing countries due to the influx of high-quality vegetable seeds/produce from developed countries that result primarily from improved vegetable crop varieties, and this has definitely had a detrimental influence of the cultivation of local crop varieties. Once consumers become adjusted to the high and consistent quality of these vegetable products, they will not accept inferior produce that oftentimes result from the cultivation of landraces. This most likely directly resulted in the loss of tomato landraces being grown and maintained in the Souss-Massa region of Morocco due to the resulting poor-quality characters, such as the high proportion of cracked or misshapen fruit, poor flavor, and low yield. Tomato landrace populations tend to be high heterogeneous mixtures that often provide many differing phenotypes under field conditions, which relate to their high amounts of genetic diversity. However, large amounts of heterogeneity in a landrace population will most likely make it unattractive to growers for several reasons, including the variation in disease control, multiple plant and fruit sizes at maturity, and inconsistent product quality and yield. The high heterogeneity of fruit and yield characters within landrace populations, limit their use for commercial plantings [2]. Thus, it is essential to identify populations that are consistent in quality and appearance (or similar to pure lines), since most farmers today are only willing to cultivate homogeneous vegetable crop populations.

\subsection{Landraces and Food Security}

Landraces are low-cost and sustainable, which is important to poor households in marginal environments that have limited monies available, such as those found in the Souss-Massa region of Morocco. The purchase of other sources of seed having much higher associated costs can leave these households vulnerable to chronic food insecurity [3]. The utilization of landrace populations by 
growers is critical for many reasons, as this allows these important resources to be perpetuated and conserved on-farm for future generations. Crop genetic resources are crucial for the future survival of humanity, and future food security depends upon their conservation [7]. Thus, without some type of on-farm genetic conservation for these crops, there is a bleak outlook for global food security [4].

\subsection{Associated Impacts of Green Revolution on Vegetable Landraces}

Since the beginning of the Green Revolution in the late 1960s and early 1970s [16], the resulting changes has been significant regarding the development and utilization of improved varieties in most cropping systems besides those high caloric crops that were initially targeted for change, which included maize, rice, and wheat. This situation has contributed significantly to the depletion of genetic diversity for most major crops grown throughout the world [4]. The results of the Green revolution has in a way caused our food systems to fail globally by not providing enough balanced nutrient/vitamin output to meet all the nutritional requirements of every person, especially resource-poor women, infants, and children in developing countries [17]. Moreover, improved crop development activities stemming from this movement have also definitely contributed to the loss of vegetable crop landraces throughout the world. The genetic diversity that exists in crop landraces is not only an economically valuable part of global diversity, but it is also of paramount importance for future world crop production [18]. Plant genetic resources remain fundamental to our efforts to improve world agricultural productivity [10]. Due to the rapid decline of landraces observed during the last half-century in many of the world's cropping systems, the genetic diversity contained within future world crop production systems will be significantly narrowed even more unless some attention is given by political infrastructures/organizations to maintain on-farm landrace conservation.

\subsection{Improving Landrace Demand in the Local Marketplace}

The Green Revolution resulted in widespread availability of hybrid vegetable seed to farmers throughout the world, which directly related to a general abandonment of vegetable landraces [19]. Although landrace utilization has definitely significantly diminished over the last few decades in Morocco, there are some instances in which specific vegetable crop landraces can still be used to provide a viable source of income. For example, in Morocco, the culture is accustomed to exceptionally sweet melons, and many landraces are still grown that have this specific characteristic. Ananas and Souehla are two types of melons that are still grown as landraces in Morocco due to their traditional consumer appeal. Both melons are very sweet and widely popular in Morocco, and also have a wide adaptability to be grown in the arid, marginal climates of this country. It is widely known that local products can enjoy a market premium since some consumers recognize their link to local culture and tradition, and are willing to pay higher prices for them [20]. Moreover, landraces that have a niche market as a traditional product are more likely to be maintained by growers [21]. Thus, the development of markets focused on local products is a method that could be used to promote landraces and to ensure their on-farm perpetuation. Although the preservation of local traditions and cultural identity, as well as product taste are all important reasons for growers to produce and maintain landraces [21], they must have an economically viable position in the marketplace before growers will make the long-term commitment to continue their on-farm perpetuation.

\section{Conclusions}

Landraces remain an important part of vegetable production systems to small landholder, subsistence farmers in the Souss-Massa region of Morocco, although their utilization in low-input, sustainable cropping systems is rapidly dwindling. Our assessment indicated that landraces of some vegetable crops, like melons, onions, and turnips, are still widely grown throughout this area of Morocco, and contribute substantially to domestic income from sales at local weekly markets. However, many different vegetable crops are rapidly being lost, and some crops (e.g., tomato) are no longer maintained as landraces. This situation is unfortunate since landrace populations have 
often evolved under strenuous climatic conditions and are well adapted to changing environmental conditions. The high amount of genetic diversity in these crop populations allows them to adapt to drought, heat, saline soil, of other extreme environmental conditions which is essential for maintaining long-term crop productivity in stressful climates, such as those found in the Souss-Massa region of Morocco. This genetic diversity is important, since it allows landrace crop populations to adapt to local effects of climate change, and to eventually produce improved yields unique to that environment. However, the utilization of heterogeneous landrace populations depends on the farmer's interest and abilities, and many are only willing to cultivate homogenous lines (e.g., pure lines or hybrids) for multiple reasons. In Morocco, vegetable crop landraces are often used by small landholders and the genetic diversity within their landraces may be the only resource available to these farmers that allows them to cope with changing environmental conditions to optimize crop production. Thus, landraces remain critical components of crop production systems for many small farmers in this region of Morocco.

Acknowledgments: The authors wish to thank the U.S. State Department Fulbright Research Scholar Program (through the Moroccan-American Commission for Educational and Cultural Exchange), Southern Illinois University-Carbondale, and the Moroccan National Institute of Agronomic Research, who all provided support for this project.

Author Contributions: Stuart Alan Walters traveled to the assessed sites, interpreted the results, and wrote most of manuscript. Rachid Bouharroud, Abdelaziz Mimouni, and Ahmed Wifaya all made grower contacts in the villages assessed, traveled to various villages, and provided interpretation services. Rachid Bouharroud also spent significant time editing the manuscript and following up with growers to obtain additional required information.

Conflicts of Interest: The authors declare no conflict of interest.

\section{References}

1. Camancho Vila, T.C.; Maxted, N.; Scholten, M.A.; Ford-Lloyd, B.V. Defining and identifying crop landraces. Plant Genet. Resour. 2005, 3, 373-384. [CrossRef]

2. Terzopoulos, P.J.; Walters, S.A.; Bebeli, P.J. Evaluation of Greek tomato landrace populations for heterogeneity of horticultural traits. Eur. J. Hortic. Sci. 2009, 74, 24-29.

3. Morris, M.L.; Bellon, M.R. Participatory plant breeding research: Opportunities and challenges for the international crop improvement system. Euphytica 2004, 136, 21-35. [CrossRef]

4. Walters, S.A. Vegetable seed availability and implications for developing countries: A perspective from Morocco. Outlook Agric. 2016, 45, 18-24. [CrossRef]

5. Sangam, D.; Ceccarelli, S.; Blair, M.W.; Upadhyaya, H.D.; Kumar, A.; Ortiz, R. Landrace germplasm for improving yield and abiotic stress adaptation. Trends Plant Sci. 2016, 21, 31-42.

6. Esquintas-Alcázar, J. Protecting crop genetic diversity for food security: Political, ethical and technical challenges. Nat. Rev. 2005, 6, 946-953. [CrossRef] [PubMed]

7. Gepts, P. Plant genetic resources conservation and utilization: The accomplishments and future of a societal insurance policy. Crop Sci. 2006, 46, 2278-2292. [CrossRef]

8. Brush, St.B.; Meng, E. Farmers' valuation and conservation of crop genetic resources. Genet. Resour. Crop. Evol. 1998, 45, 139-150. [CrossRef]

9. Khoury, C.K.; Bjorkman, A.D.; Dempewolf, H.; Ramirez-Villegas, J.; Guarino, L.; Jarvis, A.; Rieseberg, L.H.; Struik, P.C. Increasing homogeneity in global food supplies and implications for food security. Proc. Natl. Acad. Sci. USA 2014, 111, 4001-4006. [CrossRef] [PubMed]

10. Hoisington, D.; Khairallah, M.; Reeves, T.; Ribaut, J.-M.; Skovmand, B.; Taba, S.; Warburton, M. Plant genetic resources: What can they contribute toward increased crop productivity? Proc. Natl. Acad. Sci. USA 1999, 96, 5937-5943. [CrossRef] [PubMed]

11. Maxted, N.; Guarino, L.; Myer, L.; Chiwona, E.A. Towards a methodology for on-farm conservation of plant genetic resources. Genet. Resour. Crop Evol. 2002, 49, 31-46. [CrossRef]

12. Frison, E.A.; Cherfas, J.; Hodgkin, T. Agricultural biodiversity is essential for a sustainable improvement in food and nutrition security. Sustainability 2011, 3, 238-253. [CrossRef] 
13. Mavromatis, A.G.; Arvanitoyannis, I.S.; Chatzitheodorou, V.A.; Khan, E.M.; Korkovelos, A.E.; Goulas, C.K. Landraces versus commercial common bean cultivars under organic growing conditions: A comparative study based on agronomic performance and physiochemical traits. Eur. J. Hortic. Sci. 2007, 72, 214-219.

14. Frankel, O.H.; Brown, A.H.D.; Burdon, J.J. The Conservation of Plant Biodiversity; Cambridge University Press: Cambridge, UK, 1995; 299p.

15. Walters, S.A.; Groninger, J.W.; Myers, O. Rebuilding Afghanistan's agricultural economy: Vegetable production in Balkh province. Outlook Agric. 2012, 41, 7-13. [CrossRef]

16. Evenson, R.E.; Gollin, D. Assessing the impact of the green revolution, 1960 to 2000. Science 2003, 300, 758-762. [CrossRef] [PubMed]

17. Welch, R.M.; Graham, R.D. A new paradigm for world agriculture: Meeting human needs productive, sustainable, nutritious. Field Crops Res. 1999, 60, 1-10. [CrossRef]

18. Wood, D.; Lenné, J.W. The conservation of agrobiodiversity on-farm: Questioning the emerging paradigm. Biodivers. Conserv. 1997, 6, 109-129. [CrossRef]

19. Brush, S.B. The environment and native Andean Agriculture. Am. Indíg. 1980, 40, 161-172.

20. Negri, V.; Tiranti, B. Effectiveness of in situ and ex situ conservation of crop diversity: What a Phaseolus vulgaris L. landrace case study can tell us. Genetica 2010, 138, 985-998. [CrossRef] [PubMed]

21. Riu-Bosoms, C.; Calvit-Mir, L.; Reyes-García, V. Factors enhancing landrace in situ conservation in home gardens and fields in Vall De Gósol, Catalan Pyrenees, Iberian Peninsula. J. Ethnobiol. 2014, 43, 175-194. [CrossRef]

(C) 2018 by the authors. Licensee MDPI, Basel, Switzerland. This article is an open access article distributed under the terms and conditions of the Creative Commons Attribution (CC BY) license (http://creativecommons.org/licenses/by/4.0/). 